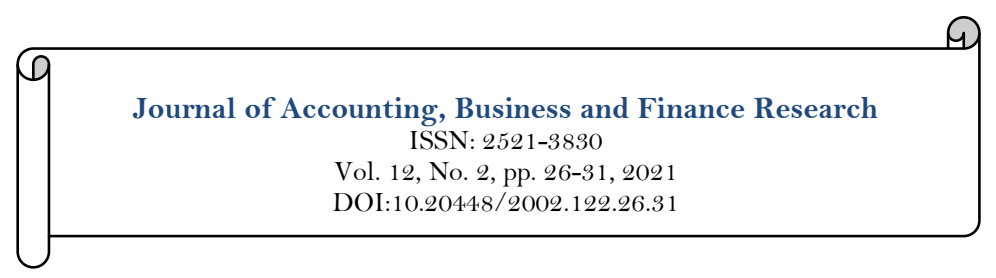

\title{
The Effect of Strengthened Corporate Governance on Firm Performance in the United States
}

\author{
Dishant Pandya \\ Ian Andrew Van Deventer ${ }^{2 s}$ \\ 'Assistant Professor of Finance, School of Business, Spalding University, Louisville, Kentucky, United States. \\ 'Assistant Professor of Accounting, School of Business, Spalding University, Louisville, Kentucky, United States. \\ Email:ivandeventer@spalding.edu
}

\begin{tabular}{|c|c|}
\hline Abstract & \\
\hline $\begin{array}{l}\text { In response to the accounting scandals of the late } 1990 \text { s, regulators } \\
\text { adopted changes to corporate governance rules in } 2003 \text { in an effort } \\
\text { to restore investor confidence in the stock market. The purpose of } \\
\text { this study is to determine whether the changes to board leadership } \\
\text { structure imposed on U.S. companies affected firm performance as } \\
\text { measured by operating return on assets. This study was conducted } \\
\text { with a sample of } 857 \text { publicly traded companies listed on the New } \\
\text { York Stock Exchange and } 11,632 \text { firm-year observations over the } \\
\text { period from } 1997 \text { to } 2012 \text {. Using a difference-in-difference estimator } \\
\text { and multivariate analysis, we found a positive and significant } \\
\text { indication that changes to board leadership structure improved the } \\
\text { long-run performance of firms that were previously insider } \\
\text { controlled. The results of this study indicate that some firms were } \\
\text { not ideally structured prior to } 2003 \text { when the changes in corporate } \\
\text { governance rules took effect for publicly traded companies listed on } \\
\text { the New York Stock Exchange. }\end{array}$ & $\begin{array}{l}\text { Keywords: } \\
\text { Corporate governance rules } \\
\text { Firm performance } \\
\text { New York Stock Exchange } \\
\text { Operating return on assets. } \\
\text { Licensed: } \\
\text { This work is licensed under a } \\
\text { Creative Commons Attribution } 4.0 \\
\text { License. } \\
\text { Publisher: } \\
\text { Scientific Publishing Institute } \\
\text { Received: } 7 \text { May } 2021 \\
\text { Revised: } 10 \text { June } 2021 \\
\text { Accepted: } 2 \text { July } 2021 \\
\text { Published: } 19 \text { July } 2021 \\
\text { (arresponding Author) }\end{array}$ \\
\hline
\end{tabular}

Funding: This study received no specific financial support.

Competing Interests: The authors declare that they have no competing interests.

\section{Introduction}

Accounting scandals of the late 1990s, such as Enron, Tyco, and WorldCom, caused such outrage that legislators quickly passed the Sarbanes-Oxley Act (SOX) on July 30, 2002, which altered corporate governance rules. Under SOX, audit committees have broadened responsibilities, management must personally certify financial reports, and companies must meet enhanced transaction disclosure requirements and comply with stringent internal control requirements (Chhaochharia \& Grinstein, 2007). The U.S. Congress passed these laws to restore the public's confidence in accounting firms.

Additional changes to corporate governance rules were made by the New York Stock Exchange (NYSE) on November 4, 2003. Under NYSE, firms must have a majority of independent directors; independent directors meet regularly without management; firms must have a nominating committee, a compensation committee, and an audit committee exclusively with independent directors; independent directors must meet strict independence requirements; and the audit committee must be financially literate and include at least one financial expert (Chhaochharia \& Grinstein, 2007). The U.S. Securities and Exchange Commission (SEC) adopted these rules to enhance corporate governance practices, specifically corporate boards and leadership structure (Bhagat \& Bolton, 2008), as cited in Rutledge, Karim, and Lu (2016), and restore investor confidence in the stock market. 
Since the changes in corporate governance rules were enacted in 2003, a new body of literature has emerged. Coles, Daniel, and Naveen (2008); Duchin, Matsusaka, and Ozbas (2008) and Linck, Netter, and Yang (2008) found that only some firms benefited from the increased monitoring. Other researchers, such as Cheng (2008); Faleye, Hoitash, and Hoitash (2011) and Faleye, Hoitash, and Hoitash (2018), found evidence that the performance of a company diminished as more independent directors were added to the firm. Faleye et al. (2011) argued that independent boards provide weaker strategic advice and erode a firm's competitive advantage over time. In contrast, Pandya and Bathala (2013) found no significant effect of independent boards on firm performance. Chen, Cheng, and Wang (2011) and Wang, Xie, and Zhu (2015) support conventional wisdom, suggesting that independent boards effectively reduce agency problems. Given the mixed results obtained by these researchers, it is difficult for regulators to determine the best way to reform corporate boards and leadership structure.

Since the 1950s, each financial crisis was followed by an increase in the percentage of independent directors serving on corporate boards to enhance corporate governance (Gordon, 2007). Lacking a strong alternative to conventional wisdom, enhancing corporate governance with independent boards was the next logical step for regulators to take to address agency problems. This study hypothesizes that the strong corporate governance rules adopted in 2003 enhance firm performance of most, if not all, non-compliant firms listed on the NYSE. We believe that previous researchers focused on short-run performance and that a study that extends several years past the independence mandate will produce positive long-run results.

We modelled our difference-in-difference methodology on Roberts and Whited (2013) and found a positive relationship between board independence and firm performance over an extended period of time. We proxy firms that do not comply with the proposed NYSE rules as those that did not have a majority of independent directors on the board at the end of the 2000 fiscal year. The results were positive and significant, indicating that some non-compliant firms were not ideally structured prior to 2003 and they benefited from the change to independent boards. Our study contributes to the body of literature by comparing firm performance over an extended period (1997-2012) and determines that short-run positive results can be sustained over longer periods of time.

\section{Literature Review}

The corporate governance literature existing prior to the changes enacted by NYSE in 2003 did not produce consistent results. Baysinger and Butler (1985) found a positive relationship between independent directors and firm performance. Agrawal and Knoeber (1996) found a negative correlation between board independence and firm performance. Other researchers, such as Rosenstein and Wyatt (1990) and Bhagat and Black (1999) found mixed results or no significant relationship between independent boards and firm performance. Most of the literature pertaining to the relationship between board independence and firm performance was written prior the changes enacted by the NYSE. As a result, there is a lack of research related to the impact of the independence mandate on firm performance.

Duchin et al. (2008) used data for 2,897 firms containing 15,820 firm-year observations from 1996 to 2005 and determined that the effect of outside directors on firm performance depends on the cost of acquiring information. When the cost of information regarding a firm's CEO and operations is low, the independent board is effective, and when the cost of information is high, the independent board is ineffective. The researchers further suggested that it may be better for some firms to be controlled by insiders as forcing these firms to adopt outsider control may decrease performance.

Linck et al. (2008) examined data from 6,931 firms and 53,602 firm-year observations over the period from 1990 to 2004 and realized that boards were structured according to the costs and benefits associated with companies' monitoring and strategic advisory needs. Firms with high growth opportunities, high R\&D expenditures, and high stock return volatility were associated with smaller and less independent boards. The boards of large firms were bigger and had more independent directors serving on them. Their findings complement Duchin et al. (2008), who pointed out that some firms performed better with independently controlled boards, while other were optimally structured with insider-controlled boards.

Coles et al. (2008) studied data from 8,165 firm-year observations from 1992 to 2001 and found that some firms, depending on their oversight or strategic advisory needs, benefited from independently controlled boards and others benefited from insider-controlled boards. Large firms that were highly leveraged tended to benefit from the additional oversight and potential conservative nature of outsider-controlled boards, and large R\&D-intensive firms tended to benefit from the firm-specific knowledge possessed by insider-controlled boards. Their findings complement Duchin et al. (2008) and Linck et al. (2008), who stated that firms benefited from different boards depending on their monitoring or strategic advisory needs.

Cheng (2008) used data from 1,252 firms and 6,869 firm-year observations from 1996 to 2004 and determined that corporate performance and corporate value became less variable as a firm's board of directors grew larger. Cheng also associated large boards with lower R\&D spending and less frequent acquisition and restructuring activities. Directors of large firms made more compromises to reach a consensus, resulting in less complex decisions and less variable firm performance. The results complement the view that independent boards provide weaker strategic advice and erode the firm's competitive advantage over time. 
Faleye et al. (2011) analyzed data from 2,051 firms and 10,636 firm-year observations from 1998 to 2006 and demonstrated that increased board monitoring comes at the cost of weaker strategic advice. They further suggested that the intense monitoring of independent boards disrupted the relationship between the board and the CEO, leading to increased leadership myopia and decreased innovation and competitive advantage. Similar to Cheng (2008), the researchers suggested that firms benefited from different boards depending on their monitoring or strategic-advising needs.

Faleye et al. (2018) studied data from 1,528 firms and 9,078 firm-year observations from 2000 to 2009 and determined that firms with directors who are industry experts serving on the board were less likely to cut R\&D spending. These findings complement their 2011 study in which they found that independent boards increased monitoring at the cost of strategic advice. Faleye et al. (2018) asserted that directors with industry expertise can provide better oversight of R\&D spending and create incentive structures that encourage executives to invest in $\mathrm{R} \& \mathrm{D}$. The researchers further argued that firm value was significantly higher when industry experts served on the boards of R\&D-intensive firms (Faleye et al., 2018).

Pandya and Bathala (2013) investigated data from 233 companies and 1,398 firm-year observations over the 2001-2006 period and found no significant effect of independent directors on firm performance. Their study, similar to many others, only investigated a three-year period after the adoption of the independence mandate. More research is needed to determine whether different results can be achieved over longer periods of time.

Chen et al. (2011) analyzed financial information from 1,205 companies from 1998 to 2006 and determined that the independent board mandate effectively reduced earnings management. These results are consistent with conventional wisdom and agency theory that independent directors are better at monitoring management than inside directors.

Wang et al. (2015) used data from 445 firms and 2,744 firm-year observations for the period from 2000 to 2007 and found that the industry expertise of independent directors significantly reduced earnings management, reduced excess CEO compensation, increased CEO turnover sensitivity, and improved returns from diversified acquisitions. These results are consistent with Chen et al. (2011), who found that independent directors led to improved monitoring of the CEO and effectively reduced agency problems.

Some of the current literature supports conventional wisdom. As predicted by agency theory, Chen et al. (2011) and Wang et al. (2015) found evidence that the new corporate governance rules benefited firms, but their results were short-term. Other researchers produced results that conflicts with conventional wisdom. In contrast to agency theory, Duchin et al. (2008); Linck et al. (2008); Coles et al. (2008); Cheng (2008); Faleye et al. (2011) and Faleye et al. (2018) found evidence that the NYSE rules reduced firm performance over a short period of time. Pandya and Bathala (2013) found no effect of the new corporate governance rules on firm performance. The current literature appears to be as inconclusive as the studies conducted prior to 2003. This may be due to the short-term data analyzed in post-2003 studies. Ours is the first study to examine data over an extended (ten-year) period following the 2003 changes to corporate governance and expands the literature on a period of time that needs more study.

2.1. Hypothesis

The literature produced before and after the 2003 NYSE independence mandate is inconclusive regarding the effect of strengthened corporate governance rules on firm performance. While researchers and academics were unable to agree on the optimal structure of the board of directors, regulators sided with conventional wisdom, believing that independent directors with no connections to management would be better than inside directors at enforcing corporate governance guidelines and reducing agency costs. Following the historical trend, we developed a hypothesis that follows conventional wisdom and predicts that the changes to board independence will have a significant and positive impact on firm performance over the long run. If conventional wisdom is correct and boards should be independent, the corporate governance rules adopted by the NYSE in 2003 should have a similar positive effect on most, if not all, firms.

$H_{i}$ : Strong corporate governance rules have a positive long-run effect on firm performance, measured by operating return on assets for firms listed on the NYSE.

\section{Research Method}

We used the difference-in-difference (DD) estimation method suggested by Roberts and Whited (2013), which approximates the results of an exogenous shock by comparing the performance of insider-controlled firms with outsider-controlled firms and removes factors that affected both groups around the time of the mandate. The standard errors are clustered across firms and are robust, and the heteroscedasticity is consistent. The following equation represents the hypothesis: Performance ${ }_{i t}=\beta_{o}+\beta_{1}$ (Inside Board ${ }^{*}$ Post Regulation $\left._{t}\right)+\Gamma X_{i t}+\delta_{i}+Y_{t}+\varepsilon_{i t}$

The primary dependent variable used to measure firm performance is operating return on assets $(O R O A)$, which is the ratio of operating income before depreciation to total assets), similar to Hermalin and Weisbach (1991) and Bhagat and Bolton (2008). 
Inside Board is the proxy for firms listed on the NYSE that are less compliant with the corporate governance rules prior to the mandate. It is a dummy variable for the firms that had a majority of inside directors in 2000, similar to Chhaochharia and Grinstein (2007); Bhagat and Bolton (2013) and Guo, Lach, and Mobbs (2015). The value for Inside Board is 0 if the ratio of outside directors to the total number of directors on the board was greater than 0.5, and the value is 1 if the ratio was equal to or less than 0.5 in 2000 .

Changes to the corporate governance rules took effect in 2003, but the changes were announced in 2002 and some firms pre-emptively adopted the rules in 2002. For this reason, 2002 was selected as the year in which the mandated changes took effect. We used Post Regulation as a dummy variable equal to 1 for 2002 and beyond. The coefficient of the interaction variable Inside Board*Post Regulation, $\beta_{1}$, is the primary variable of interest. The interaction term measures the effect of the mandate on insider-controlled firms following the regulations. If a firm already has an optimal governance structure, then changes in this structure due to the regulations should be worse for the firms that made the required changes. On the other hand, if management is entrenched, changes in board composition due to the exchange mandate should be beneficial for firms that made the required change. $X$ represents the control variables used to restore randomness. Total Assets represents the resources available for firms to generate profit. The Market-to-Book Ratio represents the company's growth opportunities. The Book Leverage Ratio represents the amount of total long-term debt the firm has. The natural log version of these variables was used. Delta $(\delta)$ indicates firm fixed effects, and upsilon $(\eta$ indicates year fixed effects. The coefficients for Inside Board and Post Regulation are absorbed by firm and year fixed effects, respectively. The constant $\left(\beta_{0}\right)$ is suppressed to avoid the dummy variable trap (similar to Adams and Ferreira (2009)) and epsilon $(\varepsilon)$ is the error term. All firm-specific variables are winsorized at the top and bottom percentiles.

\section{Results and Discussion}

The data for this study were extracted from two sources. Information regarding the board of directors comes from Institutional Shareholder Services (ISS; formerly RiskMetrics), which tracked the record of the S\&P 1500 firms from 1996 to 2009, and the companies' financial information was provided by CompuStat for

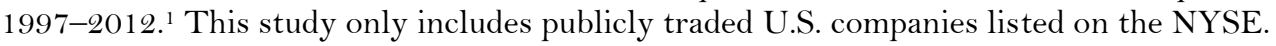

\subsection{Sample Statistics}

Table 1. Descriptive statistics for firms with outsider-controlled boards in 2000.

\begin{tabular}{l|c|c|c|c|c|c}
\hline Variable & Firms & Obs. & Mean & Std. dev. & Minimum & Maximum \\
\hline Operating return on assets & 692 & 9484 & 14.69259 & 7.830082 & -21.50504 & 38.69322 \\
\hline Book leverage ratio & 692 & 9484 & 25.73322 & 16.15564 & 0 & 94.36789 \\
\hline Market-to-book-ratio & 692 & 9484 & 2.807576 & 3.249902 & -8.769362 & 22.53574 \\
\hline Total assets & 692 & 9484 & 16544.92 & 38916.87 & 31.874 & 247816 \\
\hline
\end{tabular}

The descriptive statistics for outsider-controlled firms are displayed in Table 1. Of the total 857 firms, 692 $(81 \%)$ had an average operating return on assets of $14.69 \%$, an average book leverage ratio of $25.73 \%$, an average market-to-book-ratio of 2.81 , and average total assets of $\$ 16.5$ billion.

Table 2. Descriptive statistics for firms with insider-controlled boards in 2000.

\begin{tabular}{l|c|c|c|c|c|c}
\hline Variable & Firms & Obs. & Mean & Std. dev. & Minimum & Maximum \\
\hline Operating return on assets & 165 & 2148 & 15.85363 & 8.176232 & -20.69913 & 38.69322 \\
\hline Book leverage ratio & 165 & 2148 & 24.69361 & 19.0462 & 0 & 94.36789 \\
\hline Market-to-book ratio & 165 & 2148 & 2.993264 & 3.400685 & -8.769362 & 22.53574 \\
\hline Total assets & 165 & 2148 & 9862.75 & 30863.9 & 30863.9 & 247816 \\
\hline
\end{tabular}

The descriptive statistics for the other 165 firms (19\%) are displayed in Table 2 . Non-compliant firms had an average operating return on assets of $15.85 \%$, an average book leverage ratio of $24.69 \%$, an average marketto-book-ratio of 2.99 , and average total assets of $\$ 9.9$ billion.

Table 3. Full sample descriptive statistics for 2000

\begin{tabular}{l|c|c|c|c|c}
\hline Variable & Firms & Observations & Mean & t & P \\
\hline Operating return on assets & 857 & 11632 & 14.9070 & -2.0203 & 0.0437 \\
\hline Book leverage ratio & 857 & 11632 & 25.5412 & 0.8155 & 0.4150 \\
\hline Market-to-book-ratio & 857 & 11632 & 2.8419 & -1.0383 & 0.2994 \\
\hline Total assets & 857 & 11632 & 15310.97 & 2.1323 & 0.0333 \\
\hline
\end{tabular}

${ }^{1}$ We thank Dr. Wei Wang for sharing the data used in this study. 
Table 3 provides the descriptive statistics for the full sample of 857 publicly traded firms and 11,632 unique annual observations. The sample firms had an average operating return on assets of $14.91 \%$, an average book leverage ratio of $25.54 \%$, an average market-to-book-ratio of 2.84 , and average total assets of $\$ 15.3$ billion.

Table 3 also shows the t-values and P-values for the comparison of the outsider-controlled and insidercontrolled firms. On average, outsider-controlled firms experienced a significantly lower operating return on assets than insider-controlled firms. Additionally, outsider-controlled firms had more book leverage and a lower market-to-book-ratio than insider-controlled firms, but not significantly so. Lastly, outsider-controlled firms were significantly larger than insider-controlled firms, as measured by total assets.

4.2. Multiple Regression

Table 4. Multiple regression using difference-in-difference for the event year 2002.

\begin{tabular}{l|c|c|c|c|c|c}
\hline Variable & Firms & Obs. & Coefficient & Std. error & t & P \\
\hline Inside board*post regulation (OROA) & 857 & 11632 & 0.8453141 & 0.3886011 & 2.18 & 0.030 \\
\hline $\ln$ (Book leverage ratio) & 857 & 11632 & -1.391906 & 0.1508616 & -9.23 & 0.000 \\
\hline $\ln$ (Market-to-book-ratio) & 857 & 11632 & 4.821267 & 0.2767017 & 17.42 & 0.000 \\
\hline $\ln$ (Total assets) & 857 & 11632 & 0.2517846 & 0.1416587 & 1.78 & 0.076 \\
\hline
\end{tabular}

Table 4 depicts the multiple regression analyses of the effects of the changes in the NYSE rules on firm performance during the 1997-2012 period using difference-in-difference estimates. The interactive coefficient for Non-compliant Firms*Post Regulation is statistically significant and positive (0.845), suggesting that relative firm performance for non-compliant firms increased by almost nine-tenths a percentage point due to the mandated changes in the NYSE rules over the long run. The $\mathrm{R}^{2}$ for the model is $71.8 \%$.

Of the control variables, Book Leverage Ratio shows negative associations with firm performance in contrast to Market-to-Book Ratio and Total Assets, which each have a positive association with firm performance. Overall, the results shown in Table 4 support the conventional point of view that increased corporate governance measures improve firm performance. It is important to note that most firms benefited from the changes in the NYSE corporate governance rules.

\subsection{Falsification Test}

Table 5. Multiple regression using difference-in-difference for the event year 2000 .

\begin{tabular}{l|c|c|c|c|c|c}
\hline Variable & Firms & Obs. & Coefficient & Std. error & t & P \\
\hline Inside board*post regulation (OROA) & 857 & 5634 & 0.268902 & 0.3500848 & 0.77 & 0.443 \\
\hline ln book leverage ratio & 857 & 5634 & -1.244199 & 0.2034764 & -6.11 & 0.000 \\
\hline ln market-to-book-ratio & 857 & 5634 & 4.156728 & 0.3273905 & 12.70 & 0.000 \\
\hline ln total assets & 857 & 5634 & -0.124285 & 0.1393571 & -0.89 & 0.373 \\
\hline
\end{tabular}

To further validate the research method, we repeated the DD analysis on pre-event years (1997-2003) with a hypothetical event year in between. The purpose of this test was to prove that the observed change in board composition was the result of the exchange mandate and not the result of some alternative force. We selected 2000 as the hypothetical event year, which is two years prior to the actual event year of 2002. The results of this test are presented in Table 5 . The $\mathrm{R}^{2}$ for the model is $77.42 \%$. As expected, the DD variable is not statistically significant, suggesting that there was no event prior to the independence rules that could have affected firm performance. Additionally, the non-significance of the DD variable shows that the parallel trend assumption holds.

\section{Conclusion}

The results in Tables $1-4$ indicate that, overall, the NYSE rules forcing non-compliant firms to strengthen corporate governance measures positively impacted firm performance over the long run, which is consistent with conventional wisdom. These results complement the announcement returns observed by Chhaochharia and Grinstein (2007). Our contribution to the literature is in finding that the NYSE rules had an overall positive long-term effect on firm performance. This is also the first study to examine board composition and firm performance over a 10-year period following the 2002 exchange mandate. Further research is needed to determine whether the results are similar for firms traded on the NASDAQ, which does not require publicly traded firms to have compensation and nominating committees (Chhaochharia \& Grinstein, 2007).

\section{References}

Adams, R. B., \& Ferreira, D. (2009). Women in the boardroom and their impact on governance and performance. Journal of Financial Economics, 94(2), 291-309. https://doi.org/10.1016/j.jfineco.2008.10.007 
Agrawal, A., \& Knoeber, C. R. (1996). Firm performance and mechanisms to control agency problems between managers and shareholders. Journal of Financial and Qualitative Analysis, 31(3), 377-397. https://doi.org/10.2307/2331397

Baysinger, B. D., \& Butler, H. N. (1985). Corporate governance and the board of directors: Performance effects of changes in board composition. Journal of Law, Economics, \& Organization, 1(1), 101-124. https://doi.org/10.2307/764908

Bhagat, S., \& Bolton, B. J. (2008). Corporate governance and firm performance. Journal of Corporate Finance, 14(3), $257-273$. https://doi.org/10.1016/j.jcorpfin.2008.03.006

Bhagat, S., \& Black, B. (1999). The uncertain relationship between board composition and firm performance. Business Lawyer, 54(3), 92 1-963.

Bhagat, S., \& Bolton, B. (2013). Director ownership, governance, and performance. Journal of Financial and Quantitative Analysis, 48(1), 105-135.

Chen, X., Cheng, Q., \& Wang, X. (2011). Does increased board independence reduce earnings management? Review of Accounting Studies, 20(2), 899-933. https://doi.org/10.1007/s1 1142-015-9316-0

Cheng, S. (2008). Board size and the variability of corporate performance. Journal of Financial Economics, 87, 157-176. https://doi.org/10.1016/j.jfineco.2006.10.006

Chhaochharia, V., \& Grinstein, Y. (2007). Corporate governance and firm value: The impact of the 2002 governance rules. The Journal of Finance, 62(4), 1789-1825. https://doi.org/10.1111/j.1540-6261.2007.01257.x

Coles, J. L., Daniel, N. D., \& Naveen, L. (2008). Boards: Does one size fit all? Journal of Financial Economics, 87, 329-356. https://doi.org/10.1016/j.jfineco.2006.08.008

Duchin, R., Matsusaka, J. G., \& Ozbas, O. (2008). When are outside directors effective? Journal of Financial Economics, 96(2), 195-2 14. https://doi.org/10.1016/j.jfineco.2009.12.004

Faleye, O., Hoitash, R., \& Hoitash, U. (2011). The costs of intense board monitoring. Journal of Financial Economics, 101(1), 160-181. https://doi.org/10.1016/j.jfineco.2011.02.010

Faleye., O., Hoitash, R., \& Hoitash, U. (2018). Industry expertise on corporate boards. Review of Quantitative Finance and Accounting, 50(2), 441-479. https://doi.org/10.1007/s11156-017-0635-Z

Gordon, J. N. (2007). The rise of independent directors in the United States, 1950-2005: Of shareholder value and stock market prices. Stanford Law Review, 59(6), 1465-1568.

Guo, L., Lach, P., \& Mobbs, S. (2015). Tradeoffs between internal and external governance: Evidence from exogenous regulatory shocks. Financial Management, 44(1), 81-114.

Hermalin, B. E., \& Weisbach, M. S. (1991). The effects of board composition and direct incentives on firm performance. Financial Management, 20(4), 101-112.

Linck, J. S., Netter, J. M., \& Yang, T. (2008). The determinants of board structure. Journal of Financial Economics, 87(2), 308-328. https://doi.org/10.1016/j.jfineco.2007.03.004

Pandya, D., \& Bathala, C. (2013). Board of directors and exchange requirements: Operating performance of traditionally insider controlled boards. Journal of Applied Financial Research, 1, 88-102.

Roberts, M. R., \& Whited, T. M. (2013). Endogeneity in empirical corporate finance. In G. M. Constantinides, M. Harris, \& R. M. Stulz (Eds.), Handbook of the Economics of Finance (Vol. 2A, pp. 493-572). Netherlands: Elsevier.

Rosenstein, S., \& Wyatt, J. G. (1990). Outside directors, board independence, and shareholder wealth. Journal of Financial Economics, 26(2), 175-191. https://doi.org/10.1016/0304-405X(90)90002-H

Rutledge, R. W., Karim, K., \& Lu, S. (2016). The effects of board independence and CEO duality on firm performance: Evidence from the NASDAQ-100 index with controls for endogeneity. The Journal of Applied Business and Economics, 18(2), 49-71.

Wang, C., Xie, F., \& Zhu, M. (2015). Industry expertise of independent directors and board monitoring. Journal of Financial and Quantitative Analysis, 50(5), 929-962. https://doi.org/10.1017/S0022109015000459 